\title{
Pemimpin Kampung Tunagrahita
}

\section{Leader of Mental Retardation's Village}

\author{
Insyira Yusdiawan Azhar, Kushandajani \& Andriani Gita Swela* \\ Magister Ilmu Politik, Fakultas Ilmu Sosial dan Ilmu Politik, Universitas Diponegoro, Indonesia
}

Diterima: 24 September 2019; Disetujui: 16 November 2019; Dipublikasikan: 01 Desember 2019

\begin{abstract}
Abstrak
Penelitian ini mengulas pola kepemimpinan Eko Mulyadi selaku kepala desa dalam melakukan pemberdayaan orang-orang Tunagrahita di sebuah wilayah yang dikenal dengan Kampung Tunagrahita. Eko Mulyadi dianggap sukses dalam melakukan pemberdayaan yang berpengaruh pada kehidupan orang Tunagrahita. Menurut penelitian Putri dan Haryanti (2017), keberhasilan Mas Eko tidak lepas dari empat karakteristik kepemimpin transformasional. Akan tetapi, penelitian tersebut memiliki celah secara teoritik karena keterbatasan cakupan kepemimpinan Bass dan Riggio yang tidak mampu mengulas proses pendekatan pemimpin kepada pengikutnya. Sehingga terjadi gap yang berakibat pada lemahnya teori tersebut untuk menjelaskan bagaimana hubungan antara pemimpin dan pengikut yang sebenarnya. Tujuan penelitan ini berfokus pada proses dan dinamika, serta nilai-nilai kontekstual apa yang terjalin antara Eko Mulyadi sebagai pemimpin dengan orang-orang Tunagrahita sehingga berhasil melakukan transformasi. Penelitian ini menggunakan metode kualitatif etnografi yang dilaksanakan selama tiga minggu di lapangan dengan teknik pengumpulan data melalui observasi dan wawancara. Hasil riset ini menunjukkan bahwa gaya komunikasi, trust, reframing kepala desa terhadap Tunagrahita, dan perhatian penuh menjadi kunci keberhasilan pemberdayaan.
\end{abstract}

Kata Kunci: Kepemimpinan, Pemberdayaan, Tunagrahita

\section{Abstract}

This research will discuss the leadership pattern of Eko Mulyadi as the head village in empowering Tunagrahita people in an area known as Tunagrahita Village. Eko Mulyadi is considered successful in empowering people who have an impact on the lives of people with intellectual disabilities. According to the research of Putri and Haryanti (2017), Eko's success cannot be separated from the four characteristics of transformational leadership. However, the research has a theoretical gap because of the limited scope of Bass and Riggio's leadership who are unable to review the process of the leader approach to his followers. So there is a gap that results in the weakness of the theory to explain how the relationship between the leader and true followers. The purpose of this research focuses on the process and dynamics, as well as what contextual values are intertwined between Eko Mulyadi as a leader and people with intellectual disabilities so that they can successfully transform. This study uses a qualitative ethnographic method that is carried out for three weeks in the field with data collection techniques through observation and interviews. The results of this research indicate that the communication style, trust, reframing of the head village towards Tunagrahita, and full attention are the keys to the success of empowerment.

Keywords: Leadership, Empowerement, Mental Retardation

How to Cite: Azhar, I.Y., Kushandajani \& Swela, A.G. (2019). Pemimpin Kampung Tunagrahita. JPPUMA: Jurnal Ilmu Pemerintahan dan Sosial Politik UMA (Journal of Governance and Political Social UMA), 7 (2): 209-218

*Corresponding author: ISSN 2549-1660 (Print)

E-mail: andriani.swela@yahoo.com ISSN 2550-1305 (Online) 


\section{PENDAHULUAN}

Semenjak Eko Mulyadi menjadi kepala desa, kondisi orang-orang Tunagrahita di Desa Karangpatihan saat ini lebih baik dibandingkan beberapa tahun lalu. Dengan jumlah orang Tunagrahita sebanyak 91 orang, daerah ini dikenal sebagai "Kampung Idiot". Dalam sejarahnya, orang Tunagrahita di desa ini adalah produk akibat dari kondisi krisis pangan nasional yang terjadi pada tahun 1960-an. Krisis yang terjadi secara nasional ini ditambah dengan tidak adanya kemandirian dalam memproduksi makanan di desa, disertai dengan kondisi alam Desa Karangpatihan yang tandus dan mengalami kekeringan sehingga tidak mampu menghasilkan produk pertanian yang cukup dan berkualitas karena cadangan pangan hanya mengandalkan umbi-umbian sejenis mbote. Pada waktu itu banyak ibu-ibu yang sedang mengandung, dan kondisi mereka selama mengandung dan setelah melahirkan tidak mendapat asupan gizi yang cukup, sehingga banyak bayi lahir dalam kondisi Tunagrahita (Wawancara Mas Eko, 09/07/2019).

Novita Yosiani mendefinisikan

Tunagrahita, "sebagai orang yang mengalami hambatan dalam perkembangan mental dan intelektual sehingga berdampak pada perkembangan kognitif dan adaptifnya, seperti tidak mampu memusatkan pikirannya, emosi tidak stabil, suka menyendiri dan pendiam, peka terhadap cahaya, dll." (Yosiani, 2014). Pendapat Yosiani diperkuat dengan pendapat American Association of Mental Deficiency (AAMD) mengenai gangguan perilaku adaptif orang-orang Tunagrahita ini sebagai, "significant limitation in an individual's effectiveness in meeting the standart maturation, learning, personal independence, and/or social responsbility that are expected for his or her age level and cultural group as determined by clinical assessment and, usually, standarized scale
(Deficiency, 1983)." Selain itu, orang-orang Tunagrahita memiliki masalah akut dalam hal berkomunikasi, sehingga hal itu mempengaruhi interaksi dengan masyarakat desa.

AAMD mengklasifikasikan kedalam empat kelas Tunagrahita berdasarkan IQ: (i) Mild Mental Retardation yang memiliki IQ 50-55 hingga mencapai angkat 70; (ii) Moderate Mental Retardation yaitu 35-40 hingga 50-55; (iii) Severe Mental Retardation yaitu 20-25 hingga 35-40; (iv) Profound Mental Retardation yaitu bawah hingga 25-30 (Deficiency, 1983).

Akan tetapi kepala desa dan para pendamping hanya mengklasifikasikan Tunagrahita di desa tersebut kedalam tiga kategori, yaitu ringan, sedang, dan berat. Ketua pendamping, Pak Samuji menjelaskan pembagian kelas Tunagrahita tersebut berdasarkan perkiraan mereka mulai dari kategori ringan secara komunikasi lebih mudah untuk diajak berinteraksi. Mereka yang kategori sedang cukup sulit untuk diajak berkomunikasi. Sedangkan kategori berat adalah mereka yang sama sekali tidak bisa diajak untuk berinteraksi bahkan secara emosional cenderung agresif (Wawancara Pak Samuji, 11/07/2019).

Kemiskinan di Desa Karangpatihan terutama orang-orang Tunagrahita ini adalah kemiskinan yang selama puluhan tahun belum teratasi oleh pemerintah manapun yang berwenang, sehingga kemiskinan secara struktural yang disebabkan kesalahan sistem pemerintah yang tidak berhasil menghilangkan kemiskinan natural dan struktural berakibat pada bagaimana kemiskinan di desa selalu turun dari satu generasi ke generasi yang lain (Sumodiningrat, \& Wulandari, 2016). Hal ini ditambah dengan adanya stigma dari masyarakat yang sudah lama beranggapan bahwa orang-orang Tunagrahita ini memang orang-orang yang tidak bisa apa-apa dalam membantu perekonomian keluarga, sehingga 
menjadikan mereka teralienasi terhadap potensi kemampuan mereka dalam mendapatkan pendapatan secara mandiri.

Namun, sejak Eko Mulyadi menjadi kepala desa, pemberdayaan kepada orangorang Tunagrahita telah digalakkan. Baik tesis maupun jurnal sudah banyak yang melakukan penelitian tentang keberhasilan pemberdayaan orang-orang Tunagrahita seperti milik Amila yang menjelaskan tentang pemberdayaan Rumah Harapan ini didasari atas empat hal: penguatan modal, pelatihan usaha, penguatan pendampingan, dan penguatan pemasaran (Amila, 2017). Penelitian lain lagi seperti milik Arum dan Haryanti yang mengecikan fokus penelitian mereka bahwa pemberdayaan kerajinan keset sebenarnya tidak hanya untuk memperbaiki perekonomian Tunagrahita, tetapi juga penguatan skill dan komunikasi secara individu mereka (Arum \& Haryanti, 2017).

Selain itu, terdapat dua penelitian yang pernah dilakukan dengan fokus kajian kepemimpinan kepala desa. Pertama, peran Kepemimpinan Kepala Desa sebagai inovator dan inisiator dalam meningkatkan sumber daya masyarakat miskin dan penderita retardasi mental (Haida, 2015). Penelitian menarik lain yaitu dari Putri dan Haryanti, yang menggunakan perpaduan pola kepemimpinan yang didasarkan pada konsep inovasi dan kepemimpinan transformasional milik Bass dan Riggio(Putri \& Haryanti, 2017).

Secara teoritik, teori kepemimpinan transformasional menjadi cukup dominan bagi para penstudi kepemimpinan. Namun, Daniella Beck dalam disertasinya menunjukkan kelemahan teori tersebut. Kepemimpinan transformasional memang menjelaskan bagaimana pemimpin dalam bersikap dengan para pengikutnya, tetapi dua hal yang tidak mampu dijawab adalah, bagaimana proses dan dinamika yang terjadi selama transformasi berlangsung dan nilai-nilai kontekstual apa saja yang membentuk antara pemimpin dan pengikutnya (Beck-tauber, 2012). Dua poin penting inilah yang juga belum dijelaskan pada para peneliti sebelumnya antara Mas Eko selaku kepala desa dengan orang-orang Tunagrahita. Sehingga, atas dasar itulah penelitian ini mengangkat topik kepemimpinan Mas Eko dilihat dari konsep kepemimpinan milik Daniella Beck.

\section{METODE PENELITIAN}

Penelitian ini dilaksanakan di Desa Karangpatihan Kecamatan Balong Kabupaten Ponorogo Provinsi Jawa Timur, dengan fokus penelitian pola kepemimpinan Mas Eko pada orang Tunagrahita. Penelitian ini menggunakan metode penelitian kualitatif dan jenis penelitian deskriptif. Hal ini agar bisa memberikan gambaran secara jelas fakta di lapangan yang berkaitan dengan tujuan penelitian. Penelitian ini diarahkan untuk mengetahui dan memahami nilai yang muncul hasil interaksi sosial antara kepala desa, masyarakat sekitar, dengan orangorang Tunagrahita.

Penelitian ini menggunakan data primer dan sekunder. Data primer dilakukan dengan cara metode etnografi yang dilakukan selama tiga minggu di lapangan, dan instrumen penelitian melalui observasi dan wawancara kepada masyarakat sekitar, keluarga Tunagrahita, pemuda, para tokoh masyarakat, dan kepala desa.

Data observasi diperoleh berdasarkan pengamatan penulis tentang keseharian orang-orang Tunagrahita terutama ketika berinteraksi dengan kepala desa serta dengan para pendamping pemberdayaan. Peneliti menggunakan alat tulis untuk mencatat berbagai fenomena yang ditemui di lapangan, sehingga mampu melengkapi dalam menggambarkan fenomena di lapangan.

Sedangkan data wawancara diambil dengan beberapa orang yang memiliki keterkaitan secara langsung dengan orang 
Tunagrahita seperti kepala desa, pendamping, dan beberapa warga desa yang sering bertemu dengan orang Tunagrahita menggunakan alat perekam.

Data sekunder penulis ambil dari dua tesis dan jurnal online yang berkaitan dengan penelitian ini. Tesis pertama yaitu dari Haida (2015) dan sebuah jurnal milik Putri dan Haryanti (2017) mengulas bagaimana peran dan pola kepemimpinan yang ada pada kepala desa Karangpatihan baik sebagai inovator dan inisiator kebijakan, bahkan bertindak secara demokratis dalam membentuk kebijakan yang inovatif.

Sedangkan tesis kedua dari Amila (2017) dan Listyani \& Munawaroh (2016) membahas dari segi pemberdayaan yang telah berjalan pada orang-orang Tunagrahita. Keempat penelitian tersebut dalam penelitian ini berperan sebagai penelitian terdahulu. Penelitian ini melihat kelemahan dalam pembahasan penelitianpenelitian tersebut, sehingga, pola kepemimpinan dalam kacamata teoritik Daniella Beck mampu menjelaskan lebih mendalam bagaimana kepala desa mampu memberdayakan orang-orang Tunagrahita di Desa Karangpatihan.

\section{HASIL DAN PEMBAHASAN}

Penelitian ini menggunakan konsep Delta yang diajukan oleh Daniella Beck dalam disertasinya yang berjudul, "Transformational Leadership: Exploring Its Functionality". Dalam disertastinya Ia mengemukakan bahwa empat poin dari teori kepemimpinan transformasional Bass dan Riggio yaitu (i) idealized influence; (ii) inspirational motivation; (iii) intellectual stimulation, dan (iv) individualized consideration (Bass \& Riggio, 2006) tidak berhasil menjelaskan secara fungsionalitas bagaimana kepemimpinan seseorang mampu mempengaruhi pengikutnya. Terdapat dua poin penting yang tidak bisa dijawab oleh Bass dan Riggio: pertama, bagaimana proses dan dinamika yang terjadi. Kedua, nilai-nilai kontekstual apa yang muncul dalam proses transformasi. Sehingga, teori tersebut memiliki area "kotak hitam" yang perlu penjelasan lebih mendalam. Beck lalu merumuskan konsep yang berada di "kotak hitam" tersebut yang ia namai dengan Konsep Delta.

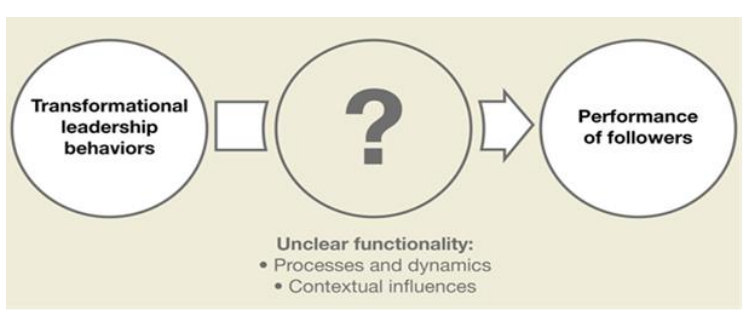

Gambar I: "Blackbox" atau gap secara teoritik.

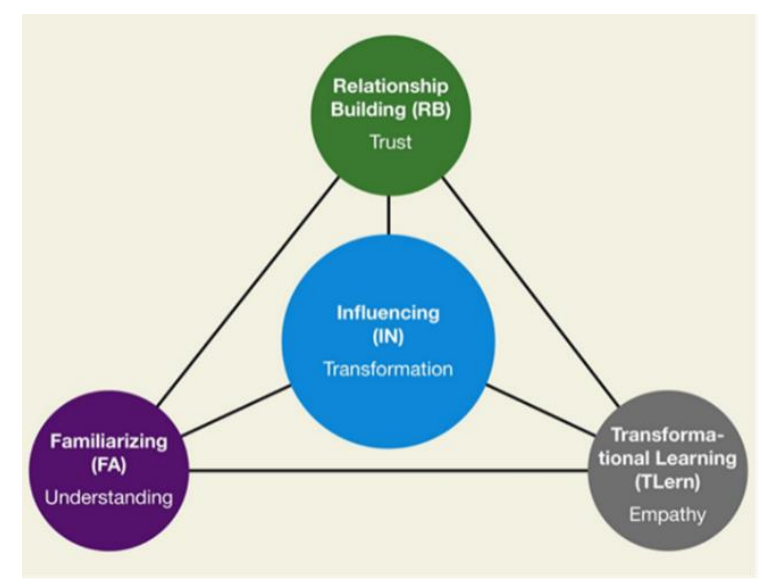

Gambar II: Konsep Delta

Terdapat empat hal poin dari konsep tersebut: (i) familiarizing menghasilkan understanding; (ii) relationship building menghasilkan trust; (iii) transformational learning menghasilkan empathy, (iv) influencing menghasilkan transformation (Beck-tauber, 2012). Selanjutnya akan dijelaskan bagaimana keempat dimensi tersebut mampu beroperasi pada studi kasus yang diangkat pada penelitian ini. 


\section{Familiarizing}

Dimensi ini menjelaskan bagaimana pemimpin berusaha dalam mendekati pengikutnya. Terdapat dua poin penting yang dibahas pada dimensi ini, yaitu, pertama, gaya komunikasi yang terbentuk antara pemimpin dengan pengikutnya. Kedua, seberapa jauh pemimpin memahami konteks perekonomian pengikutnya.

Tantangan yang dihadapi oleh kepala desa yaitu adalah seberapa jauh mereka mampu memahami orang-orang Tunagrahita yang diwujudkan kedalam komunikasi dengan orang Tunagrahita. Orang-orang Tunagrahita memiliki kesulitan dalam berkomunikasi dan itu mengecilkan ruang mereka untuk berinteraksi dengan masyarakat sekitar. Untuk Tunagrahita kategori ringan terdapat dua kategori cara berkomunikasi. Kelompok pertama, mereka mampu berbicara secara verbal dengan bahasa jawa krama inggil dengan catatan mereka tidak bisa berbicara dengan jelas dan ketika diberikan pertanyaan, seringkali mereka kesulitan mencerna pertanyaan tersebut meskipun dengan pertanyaan yang sederhana. Kelompok kedua, mereka yang tidak mampu berkomunikasi secara verbal dan hanya mengandalkan bahasa isyarat. Bahasa isyarat yang menjadi bahasa baku di desa tersebut hanyalah sebatas simbolik atas aktivitas tertentu yang mampu dipahami secara sederhana. Seperti halnya gerakan pertama tangan telunjuk menunjuk orang Tunagrahita, gerakan kedua menunjuk kita, gerakan ketiga menunjuk obyek seperti tumpukan kayu, dan gerakan keempat posisi kedua tangan diatas seperti mengangkat. Artinya "kamu bekerja untukku mengangkat kayu" (Observasi, 08/072019). Membentuk pola komunikasi dengan orang-orang Tunagrahita tentu menjadi modal utama bagi pemberdayaan. Sehingga, terjadi interaksi untuk memudahkan mereka memahami.
Meskipun mereka yang masuk pemberdayaan adalah orang-orang Tunagrahita kategori ringan yang lebih mudah diajak berkomunikasi, namun, tidak semua orang di desa maupun yang tinggal di dekat tempat tinggal orangorang Tunagrahita mampu berinteraksi dengan mereka. Bahkan, para pendamping yang menjadi tim suka relawan pemberdayaan bagi orang-orang Tunagrahita pun tidak mampu memahami dengan baik ketika berinteraksi. Meskipun para pendamping sudah mendampingi mereka selama bertahun-tahun tetapi mereka mengakui tidak paham secara keseluruhan apa yang disampaikan mereka. Selain itu, pola komunikasi yang terjadi antara pendamping dan orangorang Tunagrahita selama ini hanyalah instruktif, atau pola komunikasi satu arah. Sehingga, jarang terjadi komunikasi dua arah antara pendamping dan orang Tunagrahita (Observasi, 16/07/2019).

Pola komunikasi yang ditunjukkan oleh Mas Eko pada orang Tunagrahita berbeda dengan orang lain termasuk dengan para pendamping. Terdapat tiga hal yang penulis amati dari gaya komunikasi beliau. Pertama, Mas Eko selalu memiliki waktu tersendiri bersama mereka. Entah dalam seminggu tiga hingga empat hari selalu hadir bersama mereka. Mas Eko mengaku sering memberikan waktu luangnya bersama mereka di waktu sore hari (Wawancara Mas Eko, 09/07/2019)

Kedua, cara berkomunikasi dengan mereka. Hal yang membedakan antara Mas Eko ketika berkomunikasi dengan Tunagrahita dibandingkan orang lain adalah, Mas Eko mampu memahami setiap komunikasi mereka. Pola komunikasi yang terbentuk adalah bersifat dua arah atau komunikasi bersifat timbal balik. Ia selalu merespon setiap komunikasi yang disampaikan orang-orang Tunagrahita dengannya dan cenderung menggunakan instrumen dialog yang memungkinkan terjadi komunikasi dua arah dengan orang- 
orang Tunagrahita (Observasi,
16/07/2019). Ketiga, Mas Eko mampu menghadirkan suasana harmonis ketika berkomunikasi dengan orang Tunagrahita. Berbeda dengan orang lain yang hanya melakukan berkomunikasi biasa. Tidak jarang orang Tunagrahita tertawa bersama Mas Eko layaknya orang normal. Seperti misal ketika pemberdayaan yang dilakukan di Rumah Harapan, kondisi orang-orang Tunagrahita cukup sunyi dan yang terdengar hanya perintah atau instruksi dari Pak Samuji dan Mas Budi untuk mengerjakan kerajinan keset dan batik. Tetapi setelah Mas Eko datang untuk meninjau pemberdayaan, Ia menyapa satu persatu dan berkomunikasi dengan mereka. Suasana pun pecah dari yang awalnya hanya terdengar suara para pendamping, kemudian terdengar suara riuh tawa orang-orang Tunagrahita dan Mas Eko (Observasi, 16/07/2019).

Itu adalah fenomena yang sangat menarik karena tidak hanya sekedar berinteraksi, tetapi Mas Eko menciptakan keharmonisan dengan orang-orang Tunagrahita. Satu hal yang jelas, untuk memasuki dimensi komunikasi mereka adalah tidak mudah dan memerlukan waktu. Hal ini tidak hanya mengandalkan kebiasaan, tetapi juga dipengaruhi oleh kecerdasan seorang pemimpin untuk menciptakan improvisasi bahasa yang terjalin baik dengan orang-orang Tunagrahita (Observasi, 16/08/2019).

Selain itu, seorang pemimpin juga dituntut agar mengetahui bagaimana kondisi perekonomian dari orang-orang Tunagrahita. Dengan adanya pemberian bantuan sebelum ada pemberdayaan juga sebagai bentuk kepedulian Mas Eko pada orang-orang Tunagrahita. Mas Eko pernah bercerita bahwa beberapa orang Tunagrahita seperti Mesidi contohnya ketika mengalami masalah seperti tidak punya uang juga datang ke Mas Eko untuk pinjam uang. Baginya hal itu sudah biasa terjadi dan Ia berpandangan tetap akan membantu kebutuhan hidup orang-orang Tunagrahita (Wawancara Mas Eko, 16/08/2019).

\section{Relationship Building}

Dimensi ini membahas bagaimana hubungan yang dibangun Mas Eko dan orang-orang Tunagrahita sehingga tercipta trust diantara keduanya. Trust adalah sebuah keyakinan yang dimiliki secara personal maupun kelompok terhadap individu maupun kelompok yang lain. Terdapat empat hal yang dapat membentuk trust antara kepala desa dengan orang-orang Tunagrahita. Pertama, Mas Eko adalah orang yang lahir di wilayah yang dikelilingi orang-orang Tunagrahita. Ia bercerita bahwa sejak Ia kecil, didepan rumahnya, samping rumahnya, belakang rumahnya adalah orang-orang Tunagrahita. Sehingga, proses adaptasi itu sudah mulai Ia lakukan dengan orang-orang Tunagrahita sejak usia belia hingga dewasa sekarang. Oleh sebab itu beliau sudah memahami mengenai apa yang disukai mereka, perilaku mereka, bahkan kebutuhan mereka (Wawancara, 09 Juli 2019).

Kedua, seperti yang sudah dijelaskan sebelumnya, Mas Eko memiliki keunggulan dalam berkomunikasi dengan orang-orang Tunagrahita. Hal ini juga membuktikan intelektualitas Mas Eko. Disaat orang lain di desa banyak yang tidak mampu berkomunikasi dengan orang-orang Tunagrahita, Ia mampu menciptakan komunikasinya sendiri.

Ketiga, Mas Eko semenjak usia sekolah sudah memberikan bantuan kepada orang-orang Tunagrahita. Perhatiannya pada kehidupan orang-orang Tungrahita yang serba kekurangan membuatnya tergerak dan selalu aktif mencarikan bantuan. Ia bercerita semenjak SMA aktif di beberapa organisasi dan rajin mengumpulkan pakaian bekas untuk orang-orang Tunagrahita. Hal ini 
berlanjut ketika kuliah dan menjadi aktivis kampus, Ia sering membawa hasil daging kurban di kampusnya dan dibawa ke orang-orang Tunagrahita (Wawancara Mas Eko, 16/08/2019).

Keempat, pemberdayaan yang dilakukan Mas Eko merupakan instrumen yang menguatkan trust antar keduanya. Sebenarnya, pendidikan pemberdayaan sudah tertanam sewaktu Ia kecil ketika ayahnya mempekerjakan Mesidi. Dari sanalah Mas Eko memiliki pengetahuannya tersendiri bahwa mereka mampu diberdayakan. Sebagian orang Tunagrahita kategori ringan yang memiliki fisik prima, Ia ajak untuk mengerjakan proyek pembangunan infrastruktur seperti memecahkan dan mengangkut batu. Kemudian secara bertahap diajari pemberdayaan yang lain seperti beternak ayam, kambing, dan lele. Kemudian berlanjut pada sebagian Tunagrahita lain pemberdayaan yang dilakukan di Rumah Harapan (Wawancara Mas Eko, 16/08/2019). Sehingga, berbagai pemberdayaan yang diselenggarakan tersebut menguatkan kepercayaan orangorang Tunagrahita bahwa Mas Eko bukanlah orang yang jahat dan melakukan eksploitasi kepada mereka.

\section{Transformational Learning}

Pada dimensi ini seorang pemimpin mampu merefleksikan titik pandang, perspektif, dan bentuk yang mendasari penafsiran terhadap peristiwa. Masyarakat desa kebanyakan yang ditemui, hampir semua berpandangan pesimis tentang kehidupan orang-orang Tunagrahita karena keterbatasan secara fisik dan mental mereka. Keterbatasan secara intelektual juga berakibat pada kemampuan mereka untuk melakukan eksploitasi sumber daya ekonomi. Sehingga orang-orang Tunagrahita yang berasal dari orang miskin dan tidak berdaya, akan mewarisi kemiskinan keluarganya.
Tetapi terdapat dua pandangan Mas Eko tentang Tunagrahita yang berbeda dengan masyarakat desa lainnya: Pertama, bahwa Tunagrahita bukanlah sejenis kelainan maupun penyakit. Ia lebih memandang bahwa orang-orang Tunagrahita adalah manusia normal seperti masyarakat desa yang lain. Ia menganggap hal itu sebagai kehendak Tuhan yang ditakdirkan demikian dan tidak perlu merendahkan mereka (Wawancara Mas Eko, 16/08/2019). Sayangnya, hanya segelintir orang yang memiliki pandangan yang hampir serupa tentang orang Tunagrahita (Observasi, 09/08/2019).

Kedua, adalah pandangan optimisme dari Mas Eko bahwa orang-orang Tunagrahita adalah orang-orang normal dan memiliki potensi yang sama. Pandangan inilah yang tidak dimiliki oleh warga di desa tersebut tentang kehidupan orang-orang Tunagrahita (Wawancara Mas Eko, 16/08/2019). Pandangan ini tentu merupakan sebuah dekonstruksi pandangan pesimisme selama ini. Semua masyarakat desa memandang dari sudut pandang pesimisme dan kekurangan orang Tunagrahita. Tetapi Mas Eko memiliki pandangannya sendiri tentang orang Tunagrahita. Pada tahap ini Mas Eko tidak lagi sekedar memahami orang-orang Tunagrahita makhluk seperti apa dan menerima keberadaan mereka di desa, tetapi Ia juga "membingkai ulang" terhadap pemahamannya tentang orangorang Tunangrahita, dan juga menumbuhkan nilai baru yang Ia tanamkan pada orang Tunagrahita, yaitu materialistis.

Mas Eko mengakui bahwa justru dengan Ia menumbuhkan sifat materialistis orang Tunagrahita, itu yang membuat mereka akhirnya mau diberdayakan dan mau diajak untuk mencari uang (Wawancara Eko, 16/08/2019). 


\section{Influencing}

Pada dimensi ini, kegiatan pemberdayaan bagi orang-orang Tunagrahita sudah mulai dipikirkan bahkan direncanakan oleh Mas Eko. Beck membagi tiga tahap transformasi yaitu mulai dari generating idea, stimulating mindset, dan empowering.

Pada tahap generating idea, seorang pemimpin melakukan seleksi terhadap rencana pemberdayaan yang akan dilakukan, lalu mulai memutuskan beberapa orang yang akan melakukan pemberdayaan. Dalam hal ini, semenjak Mas Eko menjadi kepala desa, ketua kepengurusan Rumah Harapan yang menjadi sentra pemberdayaan orangorang Tunagrahita berada pada tangan Pak Samuji. Meskipun demikian, Mas Eko memberikan konsep besarnya tentang pemberdayaan bagi orang Tunagrahita yang kemudian didiskusikan dengan timnya yang mengurus Rumah Harapan sekaligus pendamping Tunagrahita. Hal ini seperti yang sudah diterangkan pada tesis Haida bahwa Mas Eko memiliki peran sebagai inovator dan inisiator pemberdayaan di desa (Haida, 2015). Penelitian yang dilakukan oleh Putri dan Haryanti (2017) juga menunjukkan bagaimana Mas Eko menganut model kepemimpinan demokratis yang selalu terbuka untuk menerima masukan dari setiap warganya dan bahkan tim pemberdayaan. Karena Mas Eko cukup rutin menyelenggarakan musyawarah (Putri\& Haryanti, 2017), sehingga proses pengambilan keputusan meliputi berbagai pihak.

Meskipun pemilihan program pemberdayaan yang dipilih adalah para pendamping yang notabene nontunagrahita, tetapi mereka tidak mengaburkan peran tunagrahita yang lain untuk ikut mendominasi dan andil dalam pemberdayaan. Sebagai contoh pasangan Tunagrahita bernama Mesidi dan Boini. Ketika akan dilakukan pemberdayaan di hari kedatangan para investor dari Bank Indonesia, dan para pendamping yang lain belum datang, Mesidi dan Boini justru datang lebih pagi lalu menyiapkan tempat pemberdayaan. Mereka terlihat rajin, dan memang ketika waktu pemberdayaan dimulai, Mesidi kerap membantu beberapa Tunagrahita lainnya, sehingga peran mereka justru membantu para pendamping yang kadang kesulitan untuk berinteraksi dengan orang-orang Tunagrahita lain (Observasi, 16/07/2019). Sehingga, keterlibatan tim sukarela ini tidak hanya para pendamping yang notabene non tunagrahita, tetapi juga keterlibatan Tunagrahita sendiri.

Pada tahap stimulating mindset yaitu sebagai sebuah cara Mas Eko dalam menggerakkan mindset orang Tunagrahita untuk bekerja. Ia menjelaskan cara agar memotivasi mereka untuk bekerja memang haruslah dengan uang atau pemberian upah bagi mereka (Wawancara, 16/08/2019).

Oleh karena itu setiap kali mereka menyetorkan hasil pekerjaannya, tanpa menunggu laku atau tidak hasil kerajinan tersebut, mereka langsung memberikan upah. Seperti dalam penelitian Listyani dan Munawaroh bahwa hal tersebut bertujuan agar mereka tidak putus asa ketika bekerja dan itu langkah memotivasi mereka (Listyani \& Munawaroh, 2016).

Pada tahap empowering ini, Rumah Harapan sebagai pusat pemberdayaan tersebut sudah berjalan tanpa Mas Eko, tetapi bukan berarti perannya tereduksi. Mas Eko tetap mengawasi bagaimana jalannya pemberdayaan. Selain itu, peran Mas Eko tetap digunakan untuk memberikan semangat pada orang-orang Tunagrahita. Melalui familiarizing seperti yang sudah dijelaskan diatas, Mas Eko melakukan pendekatan-pendekatan pada orang-orang Tunagrahita agar mereka juga giat bekerja.

Rumah Harapan sendiri sebenarnya memiliki kendala, salah satu kendala yang 
paling besar adalah modal. Mas Eko berperan besar mendatangkan bantuan pemodal seperti Bank Indonesia yang pernah memberikan bantuan modal pembuatan kolam lele. Semenjak Mas Eko menjadi kepala desa, Pak Samuji juga mengatakan bahwa peran Mas Eko sangat membantu mendorong program-program desa, salah satunya adalah untuk orangorang Tunagrahita. Modal yang dibutuhkan untuk Rumah Harapan itu nantinya akan digunakan untuk: pertama, perbaikan Rumah Harapan itu sendiri. Hal ini karena Rumah Harapan kurang layak sebagai pusat pemberdayaan karena atap rumahnya sering bocor ketika musim hujan (Observasi, 16/07/2019). Kedua, untuk memperbarui dan menambah alatalat produksi kerajinan. Ketiga, untuk menambah modal membeli bahan-bahan baik itu pembuatan kain perca untuk kerajinan keset atau kerajinan batik (Wawancara Pak Samuji, 07/072019). Sehingga, pemberdayaan secara internal dilakukan oleh tim yang sudah dibuat oleh Mas Eko. Sedangkan Mas Eko mencari dana bantuan dari pemodal demi pemberdayaan orang-orang Tunagrahita.

\section{SIMPULAN}

Konsep delta yang digagas oleh Daniella Beck pada penelitian ini mampu melengkapi celah terhadap penelitian sebelumnya mengenai peran kepemimpinan transformasional kepala desa. Keberhasilan transformasional pemberdayaan orang-orang Tunagrahita tidak lepas dari adanya proses familiarizing, relationship building, dan transformational learning. Kepala desa memiliki pendekatan khusus yang berbeda dengan orang-orang pada umumnya terutama dalam berinteraksi. Setidaknya terdapat empat poin penting kesimpulan: Pertama, Mas Eko memiliki gaya komunikasi yang harmonis ketika bersama orang-orang Tunagrahita sehingga ada proses interaksi berupa dialog setiap mereka bertemu. Kedua, adanya trust yang muncul antara keduanya yang membuat orang-orang Tunagrahita mau diajak bekerja. Ketiga, adanya reframing atas perspektif orang-orang Tunagrahita oleh Mas Eko, sehingga Ia optimis dengan adanya pemberdayaan akan mengubah nasib orang-orang Tunagrahita. Keempat, peran Mas Eko yang tidak meninggalkan program pemberdayaan orang-orang Tunagrahita meskipun terdapat tim. Setelah pemberdayaan terbentuk justru Mas Eko berperan melakukan pendekatan secara informal dengan Tunagrahita serta keluar desa karena mencari pasar dan pemodal untuk meningkatkan produksi pemberdayaan bagi orang-orang Tunagrahita.

\section{DAFTAR PUSTAKA}

Amila. (2017). Pemberdayaan Ekonomi Masyarakat Tunagrahita melalui Kelompok Swadaya Masyarakat Rumah Harapan Karangpatihan Bangkit (Studi Kasus di Desa Karangpatihan Kecamatan Balong Kabupaten Ponorogo). Malang: UIN Maulana Malik Ibrahim.

Arum \& Haryanti. (2017). Program Pemberdayaan Tunagrahita melalui Kerajinan Keset di Desa Karangpatihan Kecamatan Balong Kabupaten Ponorogo, 1(3), 16-23.

Bass \& Riggio. (2006). Transformational Leadership (Second Edition). New Jersey: Lawrence Erlbaum Assosiates.Inc.

Beck-tauber, D. (2012). Transformational Leadership: Exploring its Functionality submitted by. Universitäts-Buchbinderei Georg Konrad, Munich.

Deficiency, A. A. on M. (1983). Classification in Mental Retardation. (H. J. Grossman, Ed.) (Vol. 552). Washington DC: American Association on Mental Deficiency.

Gunawan Sumodiningrat \& Ari Wulandari. (2016). Membangun Indonesia dari Desa. Jakarta: Media Pressindo.

Haida, A. N. (2015). Kepemimpinan Kepala Desa dalam Meningkatkan Sumber Daya Manusia di Desa Karangpatihan (Studi Kasus Masyarakat Miskin dan Penderita Retardasi Mental di Desa Karangpatihan Kecamatan Balong Kabupaten Ponorogo). Universitas Gajah Mada.

Listyani \& Munawaroh, R. (2016). Praktik Sosial Pemberdayaan Masyarakat Miskin Idiot Melalui Model Kerajinan Desa Karangpatihan Kecamatan Balong Kabupaten Ponorogo. Paradigma, 04(02), 1-10. 
Insyira Yusdiawan Azhar, Kushandajani \& Andriani Gita Swela, Pemimpin Kampung Tunagrahita.

Putri, R. H. H. \& W. D. (2017). Gaya Kepemimpinan Transformasional Karangpatihan Permasalahan Karangpatihan Desa dalam Mengatasi Tunagrahita di Desa Kecamatan Balong Kabupaten Ponorogo (Suatu Kajian Inovasi Pelayanan Publik), 1(6).
Yosiani, N. (2014). Relasi Karakteristik Anak Tunagrahita dengan Pola Tata Ruang Belajar di Sekolah Luar Biasa. E-Journal Graduate Unpar, 1(2), 111-124. 